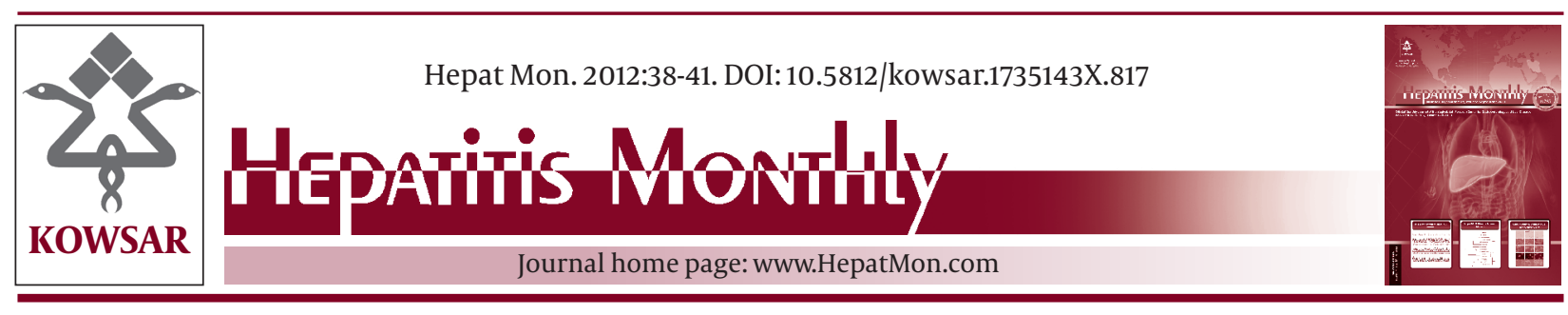

\title{
The Effect of GBV-C Infection on CD4 Count and Viral Loads in Patients Infected With HIV
}

\author{
Hossein Keyvani ${ }^{1}$, Avid Mohammadi ${ }^{2}$, Masoud Sabouri Ghannad ${ }^{3}$, Mahboobeh Hajab- \\ dolbaghi ${ }^{4}$ \\ ${ }^{1}$ School of Medicine, Tehran University of Medical Sciences, Tehran, IR Iran \\ ${ }^{2}$ Keyvan Virology Laboratory, Tehran, IR Iran \\ ${ }^{3}$ Department of Microbiology, Faculty of Medicine, Hamadan University of Medical Sciences, Hamadan, IR Iran \\ ${ }^{4}$ AIDS Research Center, Tehran University of Medical Sciences, Tehran, IR Iran
}

\begin{tabular}{l}
\hline A R T I C L E I N F O \\
\hline Article type: \\
Original Article \\
\hline Article history: \\
Received:13 Jul 2011 \\
Revised: 30 Dec 2011 \\
Accepted: 08 Jan 2012 \\
\hline
\end{tabular}

Keywords:

GB Virus C

HIV

Infection

CD4 Lymphocyte Count

\begin{abstract}
A B S T R A C T
Background: The picture that has emerged from studies investigating HIV infected people with GBV-C viremia is that they have lower plasma HIV viral loads in comparison with HIV-positive people who did not have the GBV-C viremia.

Objectives: Since GBV-C HIV coinfection has not been studied in Iran, we have designed a survey to study the outcomes of GBV-C infection on HIV infected individuals.

Patients and Methods: We analyzed 78 serum samples from HIV-positive patients in Tehran. The HIV positive statue was confirmed by Western blot in our laboratory. Next we detected GBV-C RNA by RT nested-PCR and divided our patient into GBV-C positive and GBV-C negative groups. The final step was measuring the CD4 count and HIV viral load and comparing the means of the CD4 count and HIV viral load in HIV-infected individuals in the GBV-C positive and GBV-C negative groups.

Results: We detected GBV-C RNA in 15 patients out of 78. The mean CD4 count was 607.13 compared to 415.87 in the GBV-C negative group and the difference was significant $(P=$ 0.005 ). In contrast to the $C D 4$ count there was no significant difference in HIV viral loads between HIV infected individuals in the GBV-C positive and GBV-C negative groups.

Conclusion: Although there was no significant difference in the mean of the HIV viral load between the GBV-C positive and GBV-C negative groups, the significantly higher CD4 mean in the GBV-C positive group compared with the GBV-C negative group suggests a beneficial effect of this coinfection.
\end{abstract}

Copyright $\odot 2012$ Kowsar M. P. Co. All rights reserved.

Implication for health policy/practice/research/medical education:

It has been reported that GBV-C HIV coinfection can alter the course of HIV outcomes. This article focuses on impact of GBV-C on HIV viral load and also CD4 T cell counts in coinfected patients. The results can help the clinicians and researchers to evaluate the progress of HIV-positive-individuals to AIDS.

\section{Please cite this paper as:}

Keyvani H, Mohammadi A, Sabouri Ghannad M, Hajabdolbaghi M. The Effect of GBV-C Infection on CD4 Count and Viral Loads in Patients Infected With HIV. Hepat Mon. 2012; 38-41. DOI: 10.5812/kowsar.1735143X.817

* Corresponding author: Masoud Sabouri Ghannad, Department of Microbiology, Faculty of Medicine, Hamadan University of Medical Sciences, Hamadan, IR Iran. Tel: +98-8118276295-8, Fax: +98-8118276299, E-mail: sabouri39@yahoo.com

DOI:10.5812/kowsar.1735143X.817

Copyright @2012 Kowsar M.P.Co. All rights reserved.

\section{Background}

GBV-C is a member of the Flaviviridae family and it is closely related to the hepatitis C virus (HCV) (1). A GBV$C$ infection can persist for several years, but it usually causes no obvious clinical illness or death (2). In healthy blood donors, GBV-C infection persistence occurs at rates of $1.8 \%$ (3). GBV-C infection clearance occurs in about 60\% to $70 \%$ of immunocompetent GBV-C infected people with 
the appearance of anti-E2 viral glycoprotein antibodies $(4,5)$. Furthermore, GBV-C is a blood borne virus which can also be transmitted sexually, so a high prevalence of GBV-C infection is to be expected in human immunodeficiency virus (HIV) infected people (up to $35 \%$ ) $(3,6)$. In 1998, Heringlake et al. described an association between GBV-C viremia and prolonged survival in HIV-GBV-C coinfected patients compared with HIV-infected subjects (7). The results of some studies investigating the presence of GBV-C RNA in HIV-infected patients, showed that patients with GBV-C viremia had lower mortality rates, higher baseline CD4 T cell counts and also a slower rate of decline in the number of CD4 T cells (7-12). In addition, the picture that has emerged from studies investigating HIV infected people with GBV-C viremia is that they have lower plasma HIV viral loads in comparison with HIVpositive people who did not have the GBV-C viremia (712). However, some studies did not find these potentially positive effects (13-15). To the best of our knowledge, in Iran the effects of HIV-GBV-C coinfection have not been widely evaluated and the prevalence of GBV-C in the HIV infected population has just been reported in our previous study (16). The coinfection of HIV-GBV-C can be considered variously depending on the population under study, HIV and GBV-C genotypes might be different in various geographical regions of the world.

\section{Objectives}

The main aim of this study was to design a cross-sectional study to investigate HIV-GBV-C coinfection and its effects on HIV viral load and also CD4 T cell counts in coinfected patients in Tehran, the capital of Iran.

\section{Patients and Methods}

\subsection{Study Population}

The 78 patients involved in our cross-sectional study, were selected from the Imam Khomeini Hospital in Tehran, they were classified as HIV positive by an ELISA, and we confirmed their HIV infection using the Western blot method. Data such as sex, age, transmission routes and finally HCV or HBV coinfection were collected from the patients' files (Table 1). However, we were unable to follow up 7 patients out of the 78 for further information. The patients were between 5 and 54 years (mean 34.7 years) the group consisted of $87.5 \%$ males and $12.5 \%$ females. None of our patients were prescribed anti-HIV drugs.

\subsection{Detection of GBV-C Viremia}

Viral RNA was extracted from $100 \mu$ l of serum or plasma using the acid guanidinium isothiocyanate-phenol chloroform method. For C-DNA synthesis, RT-PCR was performed at $42^{\circ} \mathrm{C}$ for $30 \mathrm{~min}$. The C-DNA was stored at $-20^{\circ}$ C. Positive and negative controls were included in each run. Positive controls were provided from the Keyvan laboratory and their GBV-C genome was sequenced at the Seqlab, Germany.

\subsection{Nested-PCR}

Two sets of primers were used in nested-PCR. External primers: HG1: 5'GCCTATTGGTCAAGAGAGAC3' HG2: 5'CACTATAGGTGGGTCTTAAG3' Internal primers:

HG3: 5'GCGCACGGTCCACAGGTGTT3'

HG4: 5'GGGCGACGTGGACCGTACGT3'

The first PCR round was run for 30 cycles $\left(94^{\circ} \mathrm{C}\right.$ for $0.5 \mathrm{~min}, 55^{\circ} \mathrm{C}$ for $1.5 \mathrm{~min}$ and $72^{\circ} \mathrm{C}$ for $\left.1.5 \mathrm{~min}\right) .10 \mu \mathrm{l}$ of product from the first PCR round was used as a template in the second PCR round. The second PCR round was for 35 cycles $\left(94^{\circ} \mathrm{C}\right.$ for $0.5 \mathrm{~min}, 55^{\circ} \mathrm{C}$ for $1.5 \mathrm{~min}$ and $72^{\circ} \mathrm{C}$ for $1.5 \mathrm{~min}$ ). PCR products were separated by agarose gel electrophoresis and visualized by ethidium bromide staining.

\subsection{HIV viral loads}

Plasma HIV RNA load was quantified by a PCR (COBAS AMOLICOR HIV-1 Monitor kit, version 1.5; Roche Molecular Systems, Switzerland)

\subsection{CD4 Cell count}

CD4 cells count was performed in the Imam Khomeini Hospital at the same time as viral loads were analyzed in our laboratory.

\subsection{Statistical analysis}

Chi square and Man Whitney tests were used in comparing CD4 cells count and HIV viral loads between GBV$C$ positive and negative groups in HIV-infected persons. A $P$ value $<0.05$ was considered significant All statistical analysis was done by SPSS software version 15 .

\section{Results}

Of the 78 patients investigated in our study the majority of patients were in the 30-40 years age group, and the major transmission route was through intravenous drug usage (Table 1). In 15 out of 78 patients, GBV-C RNA was detectable. Therefore, we divided our patients into two groups; GBV-C positive and GBV-C negative patients. Hepatitis $C$ virus (HCV) and hepatitis B virus (HBV) coinfection were also considerations in these patients. Among the HIV-infected individuals, 12 patients were infected with HCV and one was also infected with HBV (Table 2). Among the HIV-HCV infected patients, 3 patients also had GBV-C viremia. GBV-C viremia was not detected in the only patient coinfected with HCV/HBV/HIV (Table 2). The mean value of HIV viral loads and CD4 cell counts were evaluated in GBV-C positive and GBV-C negative groups (Table 3). Comparing the HIV viral load means between the GBV-C positive and GBV-C negative groups in HIV positive patients showed no significant difference $(P=0.43)$. In contrast, the mean of the CD4 cell counts among GBV$C$ positive patients was significantly higher than in the GBV-C negative patients $(P=0.005)$. 


\begin{tabular}{|c|c|c|c|}
\hline & With GBV-C RNA & Without GBV-C RNA & Pvalue \\
\hline \multicolumn{4}{|l|}{ Sex, No. (\%) } \\
\hline $\begin{array}{l}\text { Male } \\
\text { Female }\end{array}$ & $\begin{array}{l}13(21) \\
1(11.1)\end{array}$ & $\begin{array}{l}49(79) \\
8(88.9)\end{array}$ & $\begin{array}{l}0.67 \\
0.67\end{array}$ \\
\hline \multicolumn{4}{|l|}{ Age, y, No. (\%) } \\
\hline $\begin{array}{l}<10 \\
10-20 \\
20-30 \\
30-40 \\
40-50 \\
>50\end{array}$ & $\begin{array}{l}0(0) \\
0(0) \\
4(26.7) \\
6(18.2) \\
4(22.2) \\
0(0)\end{array}$ & $\begin{array}{l}1(100) \\
0(0) \\
11(73.3) \\
27(81.8) \\
14(77.8) \\
4(100)\end{array}$ & $\begin{array}{l}0.95 \\
0.95 \\
0.95 \\
0.95 \\
0.95 \\
0.95\end{array}$ \\
\hline \multicolumn{4}{|c|}{ HIV transmission routes, \% } \\
\hline $\begin{array}{l}\text { Intravenous drug use } \\
\text { Heterosexual contact } \\
\text { Blood transmission } \\
\text { Mother to infant } \\
\text { Addict + Sexual }\end{array}$ & $\begin{array}{l}83.3 \\
16.7 \\
0 \\
0 \\
0\end{array}$ & $\begin{array}{l}35.3 \\
35.3 \\
16.7 \\
5.9 \\
5.9\end{array}$ & $\begin{array}{l}\mathrm{NE}^{\mathrm{a}} \\
\mathrm{NE} \\
\mathrm{NE} \\
\mathrm{NE} \\
\mathrm{NE}\end{array}$ \\
\hline
\end{tabular}

a Abbreviations: NE, not evaluated

\begin{tabular}{llll}
\hline Table 2. HCV/HBV Coinfection Statue in HIV-Infected Individuals & & \\
\hline & GBV-C Positive, No. & GBV-C Negative, No. & Total, No. \\
\hline HIV individuals with HCV coinfection & 3 & 9 & 12 \\
HIV individuals without HCV coinfection & 12 & 53 & 65 \\
HIV individuals with HCV/HBV coinfection & 0 & 1 & 1 \\
\hline
\end{tabular}

Table 3. CD4 Count and HIV Viral Load Means in GBV-C Positive and Negative Groups

\begin{tabular}{llll}
\hline & GBV-C Positive & GBV-CNegative & Pvalue \\
\hline CD4 count & 607.13 & 415.87 & 0.005 \\
HIV viral load & 89480.73 & 92223.18 & 0.43 \\
\hline
\end{tabular}

\section{Discussion}

The effect of a GBV-C coinfection on the disease progress in HIV-infected individuals is incompletely understood. Our patients were mainly between 30-40 years old and their predominant transmission route was intravenous drug usage, which is in agreement with previous reports investigating the prevalence of HIV in Iran $(17,18)$. In our cross-sectional study, the CD4 count was higher in the GBV-C positive group compared with the GBV-C negative group in the HIV-positive individuals, and a significant difference $(P=0.005)$ was observed. However, there was no significant difference in the HIV viral loads between the GBV-C positive and negative groups $(P=0.43)$ (table 3). Similar experiences have reported on the potential influence of GBV-C on CD4 counts (19-21) Taken together, Other researches demonstrate a significant association between the presence of GBV-C RNA in the serum of HIVinfected individuals and higher CD4 counts (19-21). Hollingsworth et al. found levels of CD4 counts below 200 cell $/ \mu \mathrm{l}$ in $25 \%$ of GBV-C positive patients compared with $75 \%$ in the GBV-C negative patients $(P=0.0382)(19)$. In addition, the HIV-viral load tended to be lower, although it was not significant. Ibanez et al. and Bonacini et al. also reported a higher CD4 count in GBV-C positive patients, which was significant compared to CD4 counts in GBV$C$ negative patients. However, in the latter two studies, HIV viral loads were not considered. In contrast, Lau et al. Wooly et al. and Goubau et al. failed to show any association between the presence of GBV-C RNA and a higher CD4 count in GBV-C positive patients among HIV-infected individuals (22-24).

Part of our results obtained in this current research is consistent with the data already published. However, there are explanations for the different results obtained in our study compared to the data collected from other studies, which found positive effects or no significant effects for GBV-C HIV co-infection. The main noticeable explanation which needs to be considered is that, in most studies investigating GBV-C HIV coinfection, the investigators followed-up their patients for a period of time, in some cases over several years. Thus, they could measure CD4 counts and HIV viral loads at different periods through the years of follow-up. Also they could evaluate the progress of HIV-positive-individuals to AIDS, so they could compare the results they obtained during a period of time and also the mortality rate between GBV-C positive and GBV-C negative groups in HIV-positive individuals.

Our study was a preliminary survey to assess the GBVC HIV coinfection statue in Iran. We did not have any information regarding GBV-C genotypes in Iran which 
might have a different effect on HIV in various other geographical regions. In addition follow-up was not possible because the patients were out of reach. This was a limitation that we faced during this stage of the study. As noted above, although the CD4 count mean was significantly higher in the GBV-C positive group, the HIV viral load mean did not show a significant difference between the GBV-C positive and negative groups. Other studies showed lower HIV viral loads in the plasma of HIV-positive people who had GBV-C viremia, so there is some discrepancy in the results from our research (712). It is not unusual for different or even contradictory conclusions to be reported in the literature for similar subjects in the same field of research, as different results may be attributable to the experimental system used. In our study, although there was no significant difference between the mean of the HIV viral loads in the GBV-C positive and GBV-C negative groups, the mean of the CD4 count was significantly higher in the GBV-C positive patients in comparison with the GBV-C negative patients. Our study's results indicate a possible beneficial effect of a GBV-C coinfection with HIV.

Ongoing attempts will be undertaken to design more studies of patients infected with GBV-C and the effects of GBV-C persistent infections. As well as the genotyping of GBV-C, surveying the possible effects of other kinds of coinfections such as HCV and HBV on HIV-infected individuals and ultimately following-up the patients enrolling in such a project for a period of time, seem to be interesting ideas warranting further research in Iran.

\section{Acknowledgements}

None declared.

\section{Authors' Contribution}

All the authors had similar contribution in doing the research and writing the paper.

\section{Financial Disclosure}

None declared.

\section{Funding/Support}

None declared.

\section{References}

1. Stapleton JT. GB virus type C/Hepatitis G virus. Semin Liver Dis. 2003;23(2):137-48.

2. Alter HJ. G-pers creepers, where'd you get those papers? A reassessment of the literature on the hepatitis G virus. Transfusion. 1997;37(6):569-72.

3. Dawson GJ, Schlauder GG, Pilot-Matias TJ, Thiele D, Leary TP, Murphy P, et al. Prevalence studies of GB virus-C infection using reverse transcriptase-polymerase chain reaction. J Med Virol. 1996;50(1):97-103.

4. Thomas DL, Vlahov D, Alter HJ, Hunt JC, Marshall R, Astemborski J, et al. Association of antibody to GB virus C (hepatitis G virus) with viral clearance and protection from reinfection. J Infect Dis. 1998;177(3):539-42.

5. Lindenbach BD, Thiel HJ, Rice CM. Flaviviridae: The viruses and their replication. In: Knipe DM, Howley PT, editors. Fields Virology. 5th ed: Lippincott Williams and Wilkins.

6. Myhal ML, Laux DC, Cohen PS. Relative colonizing abilities of human fecal and K12 strains of Escherichia coli in the large intestines of streptomycin-treated mice. Eur J Clin Microbiol. 1982;1(3):186-92.

7. Heringlake S, Ockenga J, Tillmann HL, Trautwein C, Meissner D, Stoll M, et al. GB virus C/hepatitis G virus infection: a favorable prognostic factor in human immunodeficiency virus-infected patients? J Infect Dis. 1998;177(6):1723-6.

8. Toyoda H, Fukuda Y, Hayakawa T, Takamatsu J, Saito H. Effect of GB virus $\mathrm{C} /$ hepatitis $\mathrm{G}$ virus coinfection on the course of HIV infection in hemophilia patients in Japan.J Acquir Immune Defic Syndr Hum Retrovirol.1998;17(3):209-13.

9. Lefrere JJ, Roudot-Thoraval F, Morand-Joubert L, Petit JC, Lerable J, Thauvin M, et al. Carriage of GB virus C/hepatitis G virus RNA is associated with a slower immunologic, virologic, and clinical progression of human immunodeficiency virus disease in coinfected persons. J Infect Dis. 1999;179(4):783-9.

10. Yeo AE, Matsumoto A, Hisada M, Shih JW, Alter HJ, Goedert JJ. Effect of hepatitis $G$ virus infection on progression of HIV infection in patients with hemophilia. Multicenter Hemophilia Cohort Study. Ann Intern Med. 2000;132(12):959-63.

11. Xiang J, Wunschmann S, Diekema DJ, Klinzman D, Patrick KD, George SL, et al. Effect of coinfection with GB virus C on survival among patients with HIV infection. N Engl J Med. 2001;345(10):70714.

12. Tillmann HL, Heiken H, Knapik-Botor A, Heringlake S, Ockenga J, Wilber JC, et al. Infection with GB virus C and reduced mortality among HIV-infected patients. N Engl J Med. 2001;345(10):715-24.

13. Sabin CA, Devereux H, Kinson Z, Griffioen A, Brown D, Dusheiko $\mathrm{G}$, et al. Effect of coinfection with hepatitis $\mathrm{G}$ virus on HIV disease progression in hemophilic men.J Acquir Immune Defic Syndr Hum Retrovirol.1998;19(5):546-8.

14. Birk M, Lindback S, Lidman C. No influence of GB virus $C$ replication on the prognosis in a cohort of HIV-1-infected patients. AIDS. 2002;16(18):2482-5.

15. Brust D, Jagannatha S, Herpin B, Miller K, Metcalf J, Lau D. Hepatitis $G$ virus (HGV) infection does not prolong survival of patients with early-stage HIV disease: importance of baseline HIV viral load as a predictor of mortality. 14th International AIDS Conference; 2002.

16. Keyvani H, Mohammadi A, Haji-abdolbaghi M. Prevalence of GBVC RNA in HIV infected individuals in Tehran, Iran. Iran J Public Health. 2010;39(1):22-7.

17. Ghannad MS, Arab SM, Mirzaei M, Moinipur A. Epidemiologic study of human immunodeficiency virus (HIV) Infection in the patients referred to health centers in Hamadan province, Iran. AIDS Res Hum Retroviruses. 2009;25(3):277-83.

18. Ramezani A, Mohraz M, Gachkar L. Epidemiologic situation of human immunodeficiency virus (HIV/AIDS patients) in a private clinic in Tehran, Iran. Arch Iran Med. 2006;9(4):315-8.

19. Ibanez A, Gimenez-Barcons M, Tajahuerce A, Tural C, Sirera G, Clotet B, et al. Prevalence and genotypes of GB virus C/hepatitis $G$ virus (GBV-C/HGV) and hepatitis $C$ virus among patients infected with human immunodeficiency virus: evidence of GBV-C/HGV sexual transmission. J Med Virol. 1998;55(4):293-9.

20. Ibanez A, Gimenez-Barcons M, Tajahuerce A, Tural C, Sirera G, Clotet $\mathrm{B}$. Prevalence and genotyoes of $\mathrm{GB}$ virus $\mathrm{C} /$ hepatitis $\mathrm{G}$ virus (GBV-C/HGV) and hepatits $\mathrm{C}$ virus among patients infected with human immunodeficiency virus: evidence of GBV-C/HGV sexual transmission. J Med Virol. 1998;55:293-9.

21. Bonacini M, Qian D, Govindarajan S, Valinluck B. Prevalence of hepatitis G virus RNA in the sera of patients with HIV infection.J Acquir Immune Defic Syndr Hum Retrovirol. 1998;19(1):40-3.

22. Lau DT, Miller KD, Detmer J, Kolberg J, Herpin B, Metcalf JA, et al. Hepatitis $G$ virus and human immunodeficiency virus coinfection: response to interferon-alpha therapy. J Infect Dis. 1999;180(4):1334-7.

23. Woolley I, Valdez H, Walker C, Landay A, Zdunek D, Hess G, et al. Hepatitis G virus RNA is common in AIDS patients' plasma but is not associated with abnormal liver function tests or other clinical syndromes. J Acquir Immune Defic Syndr Hum Retrovirol. 1998;19(4):408-12.

24. Goubau P, Liu HF, Goderniaux E, Burtonboy G. Influence of CD4+ lymphocyte counts on GB virus C/hepatitis G virus carriership in HIV-positive individuals. J Med Virol.1999;57(4):367-9. 